\title{
DETERMINATION OF LETHAL AND FEEDING DETERRENT ACTIVITIES OF SAPONIN FROM PHALERIA MACROCARPA AGAINST POMACEA MACULATA
}

\author{
A. R. Roonjho, R. Muhamad* and D. Omar \\ Department of Plant Protection, Faculty of Agriculture Universiti Putra Malaysia \\ Corresponding Author's email: rita@upm.edu.my
}

\begin{abstract}
Apple snail is one of the major pest of rice crop and saponin proved to be the most promising bioactive compound to control it. This study was carried out to quantify saponin from God's Crown, Phaleria macrocarpa and to evaluate its efficacy against the biological activities of black apple snail, Pomacea maculata. Fruits, leaves and stem-barks of $P$. macrocarpa were quantified for saponin using HPLC. The toxicity of leaf and fruit crude extracts was evaluated through mortality and feeding deterrent bioassays using complete randomized design and data were analyzed by ANOVA for LSD test. The highest saponin contents $24.67 \mathrm{ppm}$ was detected in fruits followed by $22.67 \mathrm{ppm}$ in leaves and $5.94 \mathrm{ppm}$ in stembark. Bioassays showed the highest mortality percentage (44\%) after 24 hours exposure at the concentration of $1000 \mathrm{ppm}$ of a leaf extract followed by 36\% and 28\%@750 and 1000 ppm of leaf and fruit extracts, respectively. After the exposure of 48 hours, mortality percentage increased to 100\% @ 1000 and 750 ppm of both crude extracts while the mortality percentage recorded at the concentration of $500 \mathrm{ppm}$ of leaves and fruits were $56 \%$ and $52 \%$ respectively. Mortality percentage at the concentration of $500 \mathrm{ppm}$ was increased to $80 \%$ and $68 \%$ in leaf and fruit extracts after exposure of 72 hours, respectively. In terms of feeding deterrent, 1000, 750 and $500 \mathrm{ppm}$ concentration of both crude extracts were not significantly different from the positive control niclosamide ( $>0.05$ ). The results obtained from the study revealed that saponin extracted from fruits and leaves of $P$. macrocarpa has a potential to control black apple snails.
\end{abstract}

Key words: Phaleria macrocarpa, Pomacea maculata, HPLC, botanical molluscicides, saponins

https://doi.org/10.36899/JAPS.2021.4.0304

Published online December 18, 2020

\section{INTRODUCTION}

Pomacea spp., generally known as apple snail, belong to Family Ampullariidae from the phylum Mollusca. Apple snail is a well-known pest of rice crops in many Asian countries (Mokhtar, 2016). Historically, the pest is a South American native and introduced in Asia around 1980s as a food resource, but later it becomes a grievous pest of rice crop in many rice growing East Asian countries (Cowie, 2005; Naylor, 1996). Currently, apple snail has extended from Asia to USA, Australia and latest being in Spain, which makes it the first recorded infestation in Europe (Cowie, 2005, 1998; Eldredge, 1994; Rawlings et al., 2007). Apple snail has been acknowledged as one of the 100 invasive alien species found in the world (Lowe et al., 2000). Pomacea maculata (Black apple snail) and Pomacea canaliculata (Golden apple snail) mostly infest rice fields throughout the world (Hayes et al., 2012; Yahaya et al., 2007). Both species can be differentiated through the colour and suture structure of the shells, whereby, $P$. canaliculata is yellowish to golden with short and deeply channelled suture whereas, $P$. maculata is black with longer suture (Hayes et al., 2012). Black apple snails are more abundantly distributed in Malaysia than golden apple snails (Arfan et al., 2014). Mostly synthetic molluscicides are being used against the snails but unfortunately; these molluscicides are also well known for their adverse effects on human and environment (Mokhtar, 2016). Among the botanicals, saponin is the most promising and widely studied bioactive compound against apple snails (Mokhtar, 2016; Hostettmann et al., 1982; San Martin, 2007). Numerous studies have revealed that the haemolytic properties of saponin affect biological activities, thus, making it highly toxic to most coldblooded pests. In snails, it causes apoptosis, which leads to uncontrolled cell death (De Geyter et al., 2007; Sparg et al., 2004). Phaleria macrocarpa also known as mahkota dewa or God's crown, it is a medicinal plant indigenous to Indonesia and Malaysia. The leaves, stem barks and fruits of $P$. macrocarpa are widely known for its medicinal purpose and have been used since years as traditional medicines in Indonesia and Malaysia to treat breast cancer, bone cancer, heart and liver diseases, tumours and diabetes (Kim et al., 2010; Hending, 2009). The fruits of $P$. macrocarpa are good source of saponin (Altaf et al., 2013; Gotama et al., 1999). The stem-barks and leaves of $P$. macrocarpa have also been reported to have saponin bioactive compound (Altaf et al., 2013; Andrean et al., 2014; Gotama et al., 1999; Tjandrawinata et al., 2011). Thus, this study was conducted to quantify saponin bioactive compound in P. macrocarpa and its efficacy on the biological activities of $P$. maculata. 


\section{MATERIALS AND METHODS}

Collection and preparation of plant materials: Leaves, fruits and stem-barks of P. macrocarpa were collected in the month of June 2016 from Taman Pertanian Universiti, Universiti Putra Malaysia. The collected materials were properly washed using tap water, and then followed by distilled water. Plant materials were then dried in oven at $45^{\circ} \mathrm{C}$ for one week. The dried plant materials were then pulverized using a grinder, and the powdered material was passed through a $0.7 \mathrm{~mm}$ sieve (attached with grinder) to obtain a finer dust.

Extraction: The extraction of saponin was performed through the maceration extraction method described by Takeuchi et al. (2009) with slight modifications. Methanol was used as a solvent to isolate the bioactive compound from plant samples (Mustarichie et al., 2012). A hundred grams of each sample was placed into a $1000 \mathrm{ml}$ beaker and mixed with $700 \mathrm{~mL}$ of the solvent. The mixture was shaken for four days using an orbital shaker (Protech) and left to stand for the next 24 hours. Subsequently, the mixtures were filtered twice, once through a fine cloth and again through Whatman No.1 filter paper and finally the filtrates were ensured to be solvent free using the Rotavapour R-215 that was connected to a heating bath B149 at $40{ }^{\circ} \mathrm{C}$ and vacuum pump V-700 (BUCHI, United Kingdom) at 100 RPM. The crude extracts in the flask were transferred into glass vials and stored in a refrigerator at $-4{ }^{\circ} \mathrm{C}$ until their next use.

Quantification of saponin bioactive compound: The quantification of saponin bioactive compound was performed on Agilent 1100 series HPLC system with DAD Diode Array Detector (Agilent Technologies, USA). The method used was modified from Guo et al. (2011) and standard saponin of analytical grade from Sigma-Aldrich, USA was used as external reference of saponin. The Waters C18 column $(250 \mathrm{~mm} \times 4.6 \mathrm{~mm}, 5 \mu \mathrm{m})$ was used for separation at $254 \mathrm{~nm}$ wavelength and $25{ }^{\circ} \mathrm{C}$ column temperature. The flow rate was set at $0.7 \mathrm{ml} / \mathrm{min}$ with injection volume of $10 \mu 1$. The mobile phase was consisted of solvent A (Methanol) and solvent B (Water $+0.5 \%$ phosphoric acid) at a ratio of 50:50 v/v for 7 minutes. The signals were acquired and processed in a computer (HP) using the software ChemStation.

Rice cultivation and snails rearing: The rice was cultivated continuously in the glasshouse at Field 2, Universiti Putra Malaysia to feed the snails and to be used in bioassay experiments. Rice variety MR 219 was directly seeded into plastic containers $(28 \mathrm{~cm} \times 39 \mathrm{~cm} \times 11 \mathrm{~cm})$ filled with clay soil. The snails were collected from
Tanjung Karang paddy field, Selangor, Malaysia $\left(3^{\circ} 25^{\prime} 27^{\prime \prime} \mathrm{N} \mathrm{101^{ \circ } 1 1 ^ { \prime } 0 5 ^ { \prime \prime }}\right.$ E). The eggs, juveniles (hatchlings) and adults were handpicked. The egg masses were placed in a separate tank as they had to be kept away from water. The snails were reared in a plastic aquarium $(15 \mathrm{~cm} \times 41 \mathrm{~cm} \times 20 \mathrm{~cm})$ in the glasshouse under natural condition. Throughout the study, the aquariums were washed and the water was changed every two days to avoid contamination. Adult snails were provided with rice leaves of up to 28 days old for their consumption, whereas, one to 20 days old hatchlings were fed with algae. The black apple snails were identified based on their shell morphology (Cowie et al., 2006). Snails with shell height of $4 \mathrm{~cm}$ were used in all experiments.

Mortality bioassay: Mortality bioassay was carried out based on the guidelines for molluscicide evaluation (WHO, 1983) with slight modifications. The crude extracts of fruits and leaves were tested on P. maculata at five different concentrations $(1000,750,500,250$ and 100 ppm) along with positive control synthetic molluscicide Niclosamide (1.12 $\mathrm{ml}$ in $200 \mathrm{ml}$ of water) and negative control distilled water. For each treatment, $200 \mathrm{ml}$ of the respective solution was added to a plastic aquarium containing five apple snails. The snails were starved for 24 hours prior to the experiment, and $0.5 \mathrm{~g}$ of rice leaves were provided to the snails for feeding during the experiment. The experiment was done under Completely Randomized Design with five replications. The mortality was assessed at 24,48 and 72 hours. If the apple snails failed to show coordinated movements when softly pushed were considered dead.

Feeding deterrent bioassay: Feeding deterrent bioassay was conducted through leaf dip bioassay method described by Dawidar et al. (2012) with slight modifications. Five concentrations $(1000,750,500,250$ and $100 \mathrm{ppm})$ of both crude extracts were tested on black apple snails. Niclosamide and water were used as positive and negative controls, respectively. Five apple snails per aquarium were used in all five replications. Apple snails were starved for 24 hours before the experiment. The leaf area and weight of rice leaves were measured using LI-3100 Leaf Area Meter (LI-COR, USA) and Sartorius BT224S analytical balance (Sartorius, Germany) before and after exposure.

Statistical analysis: The experiments were carried out in CRD, and data were analysed by ANOVA for LSD test at 0.05 probability level using SAS 9.4 computer software (SAS Institute Inc. 2009). The data obtained from mortality bioassay were normalized using arcsine transformation. 


\section{RESULTS}

Extraction and quantification of saponin bioactive compound: The crude extract of fruits, leaves and stembarks of $P$. macrocarpa were used for saponin quantification. Before HPLC analysis of samples, the external standard system was used to optimize the method as it was necessary for the quantification of the compound in samples (Mradu et al., 2012). The standard saponin from Sigma-Aldrich at five different concentrations (30, $25,20,15$, and $10 \mathrm{ppm}$ ) were used to establish and calibrate the HPLC method at $\mathrm{R}^{2}(0.999)$ for saponin quantification. The retention time for saponin detection was recoded from 2.12 to 2.17 minutes. Table 1 shows the retention time, peak area, peak height, saponin content in $30 \mathrm{ppm}$ concentration of sample and saponin yield percentage obtained from the crude extracts of each plant parts that were quantified using HPLC analysis.

The highest saponin contents were $24.7 \mathrm{ppm}$ with the yield percentage of $14.8 \%$. Saponin was detected in the fruit extracts at the retention time of 2.134 minutes with peak area of $150 \mu \mathrm{V}^{*}$ sec and peak height $7.46 \mu \mathrm{V}$. The second highest saponin contents were $22.7 \mathrm{ppm}$ with the yield percentage of $14.4 \%$ and that were detected at the retention time of 2.112 minutes with peak area of 139.7 $\mu \mathrm{V}^{*}$ sec and peak height $5.72 \mu \mathrm{V}$ in the leaf extract. Meanwhile, the crude extracts of stem barks recorded the least amount of saponin which was $5.9 \mathrm{ppm}$ with yield percentage of $2.4 \%$. Saponin in stem barks of $P$. macrocarpa was detected at the retention time of 2.108 minutes with peak area of $53.48 \mu \mathrm{V}^{*}$ sec and peak height $3.11 \mu \mathrm{V}$.

Mortality bioassay: Table 2 shows the mortality percentage of $P$. maculata in different concentrations of fruits and leaves extracts of $P$. macrocarpa at 24, 48 and 72 hours. At 24 hours, both plants parts showed positive molluscicidal activities against $P$. maculata at 500, 750 and $1000 \mathrm{ppm}$ concentrations. The highest mortality percentage recorded at 24 hours was $44 \%$ in 1000 ppm of leaves extract followed by $36 \%$ in $750 \mathrm{ppm}$ of same crude extract and $28 \%$ in $1000 \mathrm{ppm}$ of fruits extract as compared to $100 \%$ mortality in positive control niclosamide.

All treatments were significantly different from positive control niclosamide at $\mathrm{P}<0.05$. The lowest mortality percentage recorded was $8 \%$ in 750 ppm of fruits extracts. Meanwhile, no dead snails were found at 24 hours in 100 and $250 \mathrm{ppm}$ of both crude extracts and negative control water. After 48 hours, the highest mortality was $100 \%$ recorded at $1000 \mathrm{ppm}$ and $750 \mathrm{ppm}$ of both crude extracts followed by $56 \%$ and $52 \%$ in 500 ppm of leaves and fruits extracts respectively. There were no dead snails found in 250 and 100 ppm of leaves and fruits extracts, as well as in untreated control at 48 hours. Leaves and fruits extract applied in higher concentrations at $1000 \mathrm{pm}$ and $750 \mathrm{ppm}$ were not significantly different from positive control niclosamide at 48 hours. This meant that the molluscicidal effects of both plants' parts were similar to niclosamide. After exposure of 72 hours, the mortality percentage in $500 \mathrm{ppm}$ of leaves and fruits crude extracts reached $80 \%$ and $68 \%$ respectively. However, no mortality was recorded in $250 \mathrm{ppm}$ and $100 \mathrm{ppm}$ of both crude extracts and water until 72 hours.

Feeding deterrent bioassay: Table 3 illustrates the mean weight of rice leaves consumed by $P$. maculata when exposed to the crude extracts of leaves and fruits. After 24 hours, the mean leaf weight consumed by black apple snails for positive control treated with niclosamide was $0.00 \pm 0.00$ g. Similarly, leaves showed no reduction in weight when treated with $1000 \mathrm{ppm}$ concentration of leaves extract. The lower the consumed leaf weight, the better the effects of crude extracts in disrupting the feeding behaviour of $P$. maculata.

The consumed leaf weight for extracts from both fruits and leaves at 1000, 750 and 500 ppm concentrations were not significantly different from niclosamide at $\mathrm{P}>0.05$, therefore, it showed similar antifeedant effects as niclosamide. The lowest consumed weight of leaves was $0.00 \pm 0.00 \mathrm{~g}$ in $1000 \mathrm{ppm}$ concentration of leaves extracts followed by $0.002 \pm 0.002 \mathrm{~g}$ at $1000 \mathrm{ppm}$ concentration of fruits extract. Meanwhile, the 250 and $100 \mathrm{ppm}$ concentrations of leaves and fruits extracts were significantly different from control niclosamide at $\mathrm{P}<0.05$. The highest mean consumed weight recorded was $0.096 \pm$ 0.006 and $0.096 \pm 0.009 \mathrm{~g}$ at $100 \mathrm{ppm}$ concentrations of leaves and fruits extracts respectively. The consumed weight of leaves at 250 and 100 ppm of both crude extracts were also significantly different at $\mathrm{P}<0.05$ from negative control water which was $0.37 \pm 0.008 \mathrm{~g}$. Table 4 shows the leaf area consumed by $P$. maculata when exposed to 1000 , $750,500,250$ and $100 \mathrm{ppm}$ concentrations of fruits and leaves extracts. After 24 hours, the lowest mean leaf area was $0.00 \pm 0.00 \mathrm{~cm}^{2}$ when treated with positive control niclosamide. Lower leaf area means, reflected better effects of crude extracts in disrupting the feeding behaviour of $P$. maculata.

In terms of leaf area consumption, the three highest concentrations of both crude extracts were not significantly different with the control niclosamide at $\mathrm{P}>0.05$. This proved that 1000, 750 and $500 \mathrm{ppm}$ concentrations of both crude extracts have the same antifeedant effects as niclosamide. However, the lowest mean area of leaves for crude extracts recorded was 0.02 $\pm 0.02 \mathrm{~cm}^{2}$ at $1000 \mathrm{ppm}$ concentration of leaves extracts followed by $0.122 \pm 0.122 \mathrm{~cm}^{2}$ at $1000 \mathrm{ppm}$ concentration of fruit extract respectively. The $250 \mathrm{ppm}$ and $100 \mathrm{ppm}$ concentrations of both crude extracts showed significant difference with negative control water at $\mathrm{P}<0.05$. The mean highest consumed leaf area recorded was $6.474 \pm$ $0.24 \mathrm{~cm}^{2}$ followed by $5.538 \pm 0.56$ for $100 \mathrm{ppm}$ concentrations of leaves and fruits extracts, respectively. 
Table 1: Saponin contents (ppm) in $30 \mathrm{ppm}$ concentration and saponin yield (\%) from different parts of $P$. macrocarpa.

\begin{tabular}{ccccccc}
\hline Plant Parts & $\begin{array}{c}\text { Ret. Time } \\
(\mathbf{m i n})\end{array}$ & Area $\left(\boldsymbol{\mu V ^ { * } \mathbf { s e c } )}\right.$ & $\begin{array}{c}\text { Height } \\
(\boldsymbol{\mu V})\end{array}$ & Area \% & $\begin{array}{c}\text { Saponin contents } \\
(\mathbf{p p m})\end{array}$ & $\begin{array}{c}\text { Saponin yield } \\
\mathbf{\%}\end{array}$ \\
\hline Fruits & 2.134 & 150.01 & 7.46 & 100 & 24.7 & 14.8 \\
Leaves & 2.112 & 139.73 & 5.72 & 100 & 22.7 & 14.4 \\
Stem-barks & 2.108 & 53.48 & 3.11 & 100 & 5.9 & 2.4 \\
\hline
\end{tabular}

Table 2: Mortality Percentage (\%) of $P$. maculata when treated with crude extracts of leaves and fruits at 24, 48, and 72 hours.

\begin{tabular}{|c|c|c|c|c|}
\hline \multirow{2}{*}{ Treatments } & \multirow{2}{*}{ Concentration (ppm) } & \multicolumn{3}{|c|}{ Mean \pm SE } \\
\hline & & $24 \mathrm{~h}$ & $48 h$ & $72 h$ \\
\hline \multirow{5}{*}{ Fruit Extract } & 1000 & $28 \pm 4.89 \mathrm{~cd}$ & $100 \pm 0.0 \mathrm{a}$ & $100 \pm 0.0 \mathrm{a}$ \\
\hline & 750 & $8 \pm 8.0 \mathrm{ef}$ & $100 \pm 0.0 \mathrm{a}$ & $100 \pm 0.0 \mathrm{a}$ \\
\hline & 500 & $12 \pm 4.89 \mathrm{ef}$ & $52 \pm 10.19 b$ & $68 \pm 4.8 \mathrm{c}$ \\
\hline & 250 & $0 \pm 0.0 \mathrm{f}$ & $0 \pm 0.0 \mathrm{c}$ & $0 \pm 0.0 \mathrm{~d}$ \\
\hline & 100 & $0 \pm 0.0 \mathrm{f}$ & $0 \pm 0.0 \mathrm{c}$ & $0 \pm 0.0 \mathrm{~d}$ \\
\hline \multirow{5}{*}{ Leaves Extract } & 1000 & $44 \pm 7.48 b$ & $100 \pm 0.0 \mathrm{a}$ & $100 \pm 0.0 \mathrm{a}$ \\
\hline & 750 & $36 \pm 7.4 \mathrm{bc}$ & $100 \pm 0.0 \mathrm{a}$ & $100 \pm 0.0 \mathrm{a}$ \\
\hline & 500 & $20 \pm 6.32 \mathrm{de}$ & $56 \pm 7.4 b$ & $80 \pm 8.9 b$ \\
\hline & 250 & $0 \pm 0.0 \mathrm{f}$ & $0 \pm 0.0 \mathrm{c}$ & $0 \pm 0.0 \mathrm{~d}$ \\
\hline & 100 & $0 \pm 0.0 \mathrm{f}$ & $0 \pm 0.0 \mathrm{c}$ & $0 \pm 0.0 \mathrm{~d}$ \\
\hline \multirow[b]{2}{*}{ Control } & Niclosamide & $100 \pm 0.0 \mathrm{a}$ & $100 \pm 0.0 \mathrm{a}$ & $100 \pm 0.0 \mathrm{a}$ \\
\hline & Untreated & $0 \pm 0.0 \mathrm{f}$ & $0 \pm 0.0 \mathrm{c}$ & $0 \pm 0.0 \mathrm{~d}$ \\
\hline
\end{tabular}

Means with same letters within column are not significantly different at $\mathrm{P}>0.05$

Table 3: Mean leaf weight (g) consumed by $P$. maculata when treated with crude extracts of leaves and fruits.

\begin{tabular}{ccc}
\hline Treatments & Concentration $(\mathbf{p p m})$ & Mean \pm SE \\
\cline { 2 - 3 } & 1000 & Weight \\
\hline \multirow{2}{*}{ Fruit Extract } & 750 & $0.002 \pm 0.002 \mathrm{e}$ \\
& 500 & $0.004 \pm 0.002 \mathrm{e}$ \\
& 250 & $0.01 \pm 0.003 \mathrm{e}$ \\
& 100 & $0.072 \pm 0.015 \mathrm{c}$ \\
Leaves Extract & 1000 & $0.096 \pm 0.006 \mathrm{~b}$ \\
\hline & 750 & $0.00 \pm 0.00 \mathrm{e}$ \\
& 500 & $0.006 \pm 0.004 \mathrm{e}$ \\
Control & 250 & $0.012 \pm 0.005 \mathrm{e}$ \\
& 100 & $0.05 \pm 0.004 \mathrm{~d}$ \\
& Niclosamide & $0.096 \pm 0.009 \mathrm{~b}$ \\
\hline
\end{tabular}


Table 4: Mean leaf area $\left(\mathrm{cm}^{2}\right)$ consumed by $P$. maculata when treated with crude extracts of leaves and fruits.

\begin{tabular}{ccc}
\hline Treatments & Concentration (ppm) & Mean \pm SE \\
\cline { 2 - 3 } & 1000 & Area \\
\hline \multirow{2}{*}{ Fruit Extract } & 750 & $0.122 \pm 0.122 \mathrm{e}$ \\
& 500 & $0.404 \pm 0.24 \mathrm{e}$ \\
& 250 & $0.714 \pm 0.28 \mathrm{e}$ \\
& 100 & $3.902 \pm 0.33 \mathrm{c}$ \\
Leaves Extract & 1000 & $6.474 \pm 0.24 \mathrm{~b}$ \\
\hline & 750 & $0.02 \pm 0.02 \mathrm{e}$ \\
& 500 & $0.482 \pm 0.288 \mathrm{e}$ \\
Control & 250 & $0.884 \pm 0.38 \mathrm{e}$ \\
& 100 & $2.306 \pm 0.58 \mathrm{~d}$ \\
& Niclosamide & $5.538 \pm 0.56 \mathrm{~b}$ \\
\hline
\end{tabular}

Means with same letters within column are not significantly different at $\mathrm{P}>0.05$

\section{DISCUSSION}

Extraction and quantification of saponin bioactive compound: Previous study on the crude extract from the fruits of $P$. macrocarpa showed the presence of bioactive compounds such as saponin glycosides, tannins, phenols, and flavonoids (Lay et al. 2014). Altaf et al. (2013) and Andrean et al. (2014) had also highlighted that the fruits of $P$. macrocarpa are rich in saponin bioactive compound. Similarly, the HPLC analysis results of this study supported this observation. The fruit extracts of $P$. macrocarpa contained $82.4 \%$ of saponin while the yield of crude extract from dried powder of fruits of $P$. macrocarpa was $18 \%$ so the total yield of saponin from fruits was recorded $14.8 \%$. This strongly supports the $P$. macrocarpa fruits as a main source of saponin bioactive compound, thus, confirming that saponin was the main bioactive compound in the fruits of P. macrocarpa. This finding is crucial, as future extraction of saponin from this plant can be targeted on the fruits as it can yield high quantity.

As detected by the HPLC analysis, the leaves extracts were found to be the second richest in saponin content. Total saponin amount was $75.7 \%$ while the yield of crude extract from dried powder of Leaves of $P$, macrocarpa was $19 \%$ therefore; the saponin yield \% was 14.4 in leaves. Previous studies have reported the presence of saponin bioactive compound in the leaves of $P$. macrocarpa, together with tannins and flavonoids (Shodikin, 2010; Faried et al., 2016). Previously, some other studies also reported presence of saponin and alkaloids in leaf extracts of $P$. macrocarpa and proposed the use of $P$. macrocarpa leaves for antibacterial purposes (Elianora et al., 2017; Altaf et al., 2013). Furthermore, the yield of crude extract from leaves was higher comparing with fruits. This further proved that the leaves are also a suitable source of saponin.

The HPLC analysis of the stem-barks extracts revealed the lowest saponin content in comparison to all the other plant parts. Although previous studies have reported the presence of saponin bioactive compound in the stem-barks of P. macrocarpa (Gotama et al., 1999; Altaf et al., 2013). But based on the HPLC analysis in this study, only $5.94 \mathrm{ppm}$ of saponin was detected in $30 \mathrm{ppm}$ of crude extract which were only $19.8 \%$ and the yield of crude extracts was also low as it was only $12 \%$ and total saponin yield from stem-barks was only $2.4 \%$. The low saponin content in the barks reports as an inefficient source of saponin as compared to the leaves and fruits of $P$. macrocarpa.

Mortality bioassay: The results obtained from mortality bioassay proved that saponin extracted from fruits and leaves of $P$. macrocarpa have the potential to kill apple snails as early as 24 hours. Previous studies had also recorded the molluscicidal effects of saponin from Furcraea spp. on apple snails at 24 hours (Osman et al., 2011; Jose et al., 2013; Mokhtar, 2016). It was also observed that saponin from fruits and leaves could show $100 \%$ mortality after 48 hours. Similarly, some previous studies also revealed that saponin from Entada phaseolides could achieve 80 to $100 \%$ mortality against apple snails after 48 hours of exposure (Morallo-Rejesus and Maini, 1991; Morallo-Rejesus et al., 1995; Rejesus and Punzalan, 1997). As observed in this study, the effectiveness of both crude extracts was directly relative to the time of exposure to the saponin concentration. If the exposure time to saponin increased the egg laying capacity, growth rate and survival rate of freshwater apple snails also decreased (Mahato et al., 1982). 
Feeding deterrent bioassay: The results of this study from feeding deterrent bioassay revealed that apple snails avoid the saponin treated diet, some previous studies also recorded $0 \%$ leaf damaged in lettuce caused by snails at 4 hours when treated with 3\% ethanolic Myrrh (Ali, 2005). Another study also reported $19 \%$ damage in rice seedlings when treated with methanolic extract of dried neem leaves (Latip et al., 2017). Higher saponin contents lowered the feeding activities of snails, as saponin displayed molluscicidal properties against apple snails (Huang et al., 2003). Additionally, the noxious odour produced can also prevent apple snails from consuming rice leaves. Higher concentration of crude extracts of saponin containing plants, reduced the feeding attraction of apple snails towards rice leaves (Mokhtar, 2016). Besides of saponin's direct molluscicidal and insecticidal activities, it is also very well-known for its antifeedant properties. Therefore, plants that containing saponin could also serve as an antifeedant to prevent molluscs from feeding on living plants. (Mason et al., 1994; Chaieb et al., 2009), This supported the finding in the anti-feedant bioassays conducted in this research.

Conclusion: Methanolic extracts of fruits and leaves of $P$. macrocarpa are rich in saponin and showed strong bioactivities against black apple snails. Therefore, it is recommended that it should be further investigated as an eco-friendly cost effective botanical molluscicide.

\section{REFERENCES}

Ali, A., (2005). Repellent, Antifeedant \& Molluscicidal Effects of Commiphora spp. Oleoresins, and their extracts, on Deroceras reticulatum and Helix aspersa (Doctoral thesis). Cardiff University, United Kingdom.

Altaf, R., M. Z. B. Asmawi, A. Dewa, A. Sadikun and M. Umar (2013). Phytochemistry and medicinal properties of Phaleria macrocarpa (Scheff.) Boerl. extracts. Pharmacogn. Rev. 7: 73. https://doi.org/10.4103/0973-7847.112853

Andrean, D., S. Prasetyo, A.P. Kristijarti and T. Hudaya (2014). The Extraction and Activity Test of Bioactive Compounds in Phaleria Macrocarpa as Antioxidants. Procedia Chem. 9: 94-101. https://doi.org/10.1016/j.proche.2014.05.012

Arfan, A.G., R. Muhamad, D. Omar, A.A.N. Azwady and G. Manjeri (2014). Distribution of two Pomacea spp . in Rice Fields of Peninsular Malaysia. Annu. Res. Rev. Biol. 4: 4123-4136. https://doi.org/10.9734/ARRB/2014/11398

Chaieb, I., M. Kamel, H. Hialima and M.H. Hamouda (2009). Antifeedant activity of Cestrum parqui crude saponic extract . Tunis. J. Med. Plants Nat. Prod. 1: 27-33.

Cowie, R.H., (2005). The Golden Apple Snail : Pomacea species including Pomacea canaliculata ( Lamarck, 1822 ) ( Gastropoda : Ampullariidae ).

Cowie, R.H., (1998). Patterns of introduction of nonindigenous non-marine snails and slugs in the Hawaiian Island. Biodivers. Conserv. 7: 349368.

Cowie, R.H., K.A. Hayes and S.C. Thiengo (2006). What are the apple snails? Confused txanomy and some preliminary resolution, in: Joshi, R.C., Sebastian, L.S. (Eds.), Global Advances in Ecology and Management of Apple Snails. pp. 2-23.

Dawidar, A.E.M., M.M. Mortada, H.M. Raghib and M. Abdel-Mogib, (2012). Molluscicidal activity of Balanites aegyptiaca against Monacha cartusiana. Pharm. Biol. 50: 1326-1329. https://doi.org/10.3109/13880209.2012.674950

De Geyter, E., E. Lambert, D. Geelen and G. Smagghe (2007). Novel advances with plant saponins as natural insecticides to control pest insects. Pest Technol. 1: 96-105. https://doi.org/ 10.1.1. 455.4613

Eldredge, L.G., (1994). Perspectives in aquatic exotic species management in the Pacific Islands. Pacific Sci. Assoc., Honolulu, hawaii, USA

Elianora, D., B. Busman and Y. Amrilya (2017). Activities test of Mahkota Dewa (Phaleria macrocarpa) leaves extract against Candida albicans of HIV/AIDS patients. Padjadjaran J. Dent. 29: 1-7. https://doi.org/10.24198/ pjd.vol29no1.11588

Faried, A., H. Bolly, L. Septiani, D. Kurnia, M. Arifin and F. Wirakusumah (2016). Potential of Indonesian Herbal Medicine, Phaleria macrocarpa (Scheff.) Boerl, for Targeting Multiple Malignancy Signaling Pathways: An Introductory Overview. European J. Med. Plants. 11: 1-17. https://doi.org/10.9734/ EJMP/2016/20760

Gotama, I.B.I., S. Sugiarto, M. Nurhadi, Y. Widiyastuti, S. Wahyono and I.J. Prapti (1999). Inventaris tanaman obat Indonesia. 5th Ed. Deptt. kesehatan Bandan. Pen. dan Peng. Jakarta.

Guo, S.,J. Duan, Y. Tang, Y. Qian, J. Zhao, D. Qian, S. Su and E. Shang, (2011). Simultaneous qualitative and quantitative analysis of triterpenic acids, saponins and flavonoids in the leaves of two Ziziphus species by HPLC-PDA-MS/ELSD. J. Pharm. Biomed. Anal. 56: 264-270. https://doi.org/10.1016/j.jpba.2011.05.025

Hayes, K.A., R.H. Cowie, S.C. Thiengo, and E.E Strong (2012). Comparing apples with apples: Clarifying the identities of two highly invasive Neotropical Ampullariidae (Caenogastropoda). Zool. J. Linn. Soc. 166: 723-753. https://doi.org/10.1111/j.1096-3642.2012.00867.

Hending, W., (2009). Benzophenone glucoside isolated from the ethyl acetate extract of the bark of mahkota dewa (Phaleria macrocarpa (Scheff.) 
Boerl.) and its inhibitory activity on leukemia L1210. Indo J. Chem. 9 (1):142-145.

Hostettmann, K., H. Kizu and T. Tomimori (1982). Molluscicidal properties of various saponins. Planta Med. 44: 34-35. https://doi.org/10.1055/s2007-971396

Huang, H.C., S.C. Liao, F.R. Chang, Y.H. Kuo and Y.C. $\mathrm{Wu}$ (2003). Molluscicidal saponins from Sapindus mukorossi, inhibitory agents of golden apple snails, Pomacea canaliculata. J. Agric. Food Chem. 51: 4916-4919. https://doi.org/10.1021/jf0301910

Jose, I., A. Lorena and A. Hildebrando (2013). Toxicity of the Biopesticides Agave americana, Furcraea andiana (Asparagaceae) and Sapindus saponaria (Sapindaceae) on invader snail Melanoides tuberculata (Thiaridae) Neotrop. Helminthol. 7: 2218-6425.

Kim, W.-J., B. Veriansyah, Y.W. Lee, J. Kim and J.D. Kim (2010). Extraction of mangiferin from Mahkota Dewa (Phaleria macrocarpa) using subcritical water. J. Ind. Eng. Chem. 16: 425-430. https://doi.org/10.1016/j.jiec.2009.08.008

Latip, S., H.M. Noor, M.F. Keni and R. Rosli (2017). Antifeedant Activities of Neem Seed Extracts for Controlling Golden Appple Snail, Pomacea canaliculata. Soc. Sci. 12: 294-298.

Lay, M.M., S.A. Karsani, B. Banisalam, S. Mohajer and S.N. Abd-Malek (2014) Antioxidants, phytochemicals, and cytotoxicity studies on Phaleria macrocarpa (Scheff.) Boerl Seeds. Biomed Res. Int. 1-13. https://doi.org/10.1155/ 2014/410184

Lowe, S., M. Browne, S. Boudjelas and M. De-Poorter (2000). 100 of the world's worst invasive alien species a selection from the global invasive species data base. The Invasive Species Specialist Group (ISSG)., Aliens.

Mahato, S.B.,A.N. Ganguly and N.P. Sahu (1982). Steroid saponins. Phytochemistry 21: 959-978. https://doi.org/10.1016/S0031-9422(00)82400-0

Mason, W.M.A., G.S. Puritch and D.S. Almond (1994). Saponin containing anti-feedant and molluscicide for terrestrial mollusk control. Patent No. US 5290557 A.

Mokhtar, A, S., (2016). Nano emulsion formulation of saponin to control black apple snails, Pomacea maculata Perry (Doctoral thesis). Univ. Putra Malaysia, Serdang, Malaysia.

Morallo-Rejesus, B and P.N. Maini (1991). Sapogenic plant material for golden snail ( Pomacea spp.) control. Phase-I.

Morallo-Rejesus, B., P.N. Maini and E. Punzalan (1995). Sapogenic plant materials foe golden snail ( Pomacea spp.) control. Phase-II.

Mradu, G., S. Saumyakanti, M. Sohini, and M. Arup
(2012). HPLC profiles of standard phenolic compounds present in medicinal plants. Int. J. Pharmacogn. Phytochem. Res. 4: 162-167.

Mustarichie, R., Z. Udin, A. Muhtadi, E. Surahman and A. Subarnas (2012). The antioxidant activity and cytotoxicity of methanol extracts from cranberry plants. Int. Res. J. Pharm. Appl. Sci. 2: 56-61.

Naylor, R., (1996). Invasions in Agriculture: Assessing of the Golden Apple Snail in Asia the. Ambio 25: 443-448.

Osman, G.Y., A.M. Mohamed, A.A Kader and A.A. Mohamed (2011). Biological studies on Biomphalaria alexandrina snails treated with Furcraea selloa marginata plant (family: Agavaceae) and Bacillus thuringiensis kurstaki (Dipel-2x). J. Appl. Pharm. Sci. 1: 47-55.

Rawlings, T.A., K.A. Hayes, R.H. Cowie, and T.M. Collins (2007). The identity, distribution, and impacts of non-native apple snails in the continental United States. BMC Evol. Biol. 7: 114. https://doi.org/10.1186/1471-2148-7-97

Rejesus, H.M. and E.G. Punzalan (1997). Molluscicidal Action of Some Philippine Plants on Golden Snails , Pomacea Spp . Phil. Entomol. 11: 65-79.

San Martin, R. (2007). Recent development in the use botanical molluscicides against apple snail, (Pomacea canaliculata),, in: R.C., J., L.S., S. (Eds.), Global Advances in Ecology and Management of Golden Apple Snails. PhilRice, Neur Ecija, Philippines, pp. 393-403.

Shodikin, M.A. (2010). Antimicrobial activity of mahkota dewa (Phaleria macrocarpa (Scheff). Boerl) leaf extract againts Pseudomonas aeruginosa by agar dilution and scanning electron microscopy. Folia Medica Indones. 46, 172-178.

Sparg, S.G., M.E. Light and J. Van Staden (2004). Biological activities and distribution of plant saponins. J. Ethnopharmacol. 94: 219-243. https://doi.org/10.1016/j.jep.2004.05.016

Takeuchi, T.M., C.G. Pereira, M.E.M. Braga, M.R. Maróstica, P.F. Leal and M.A.A. Meireles (2009). Low-pressure solvent extraction (solidliquid extraction, microwave assisted, and ultrasound assisted) from condimentary plants., in: Meireles, M.A.A. (Eds. . (Ed.), Extracting Bioactive Compounds for Food $\mathrm{p}$ RoductsTheory and Applications. CRC Press, Boca Raton, pp. 151-158.

Tjandrawinata, L., D. Nofiarny, L.W. Susanto, P. Hendri and A. Clarissa (2011). Symptomatic treatment of premenstrual syndrome and/or primary dysmenorrhea with DLBS1442, a bioactive extract of Phaleria macrocarpa. Int. J. Gen. Med. 465. https://doi.org/10.2147/IJGM.S21053

WHO, (1983). Reports of the scientific working group on plant molluscicides. Bull. World Heal. Organ. 61, 
927-929.

https://doi.org/http://apps.who.int/iris/handle/10 665/60086

Yahaya, H., M. Nordin, M.N. Mohamad-Hisham and A.
Sivapragasam (2007). Golden apple snails in Malaysia., in: Joshi, R.C., Sebastian, L.S. (Eds.), Global Advances in Ecology and Management of Golden Apple Snails. pp. 215-230. 